\title{
Drugs for relief of pain in patients with sciatica: systematic review and meta-analysis
}

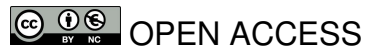

\author{
Rafael Zambelli Pinto PhD student ${ }^{1}$, Chris G Maher director ${ }^{1}$, Manuela L Ferreira research fellow ${ }^{1}$, \\ Paulo H Ferreira senior lecturer ${ }^{2}$, Mark Hancock senior lecturer ${ }^{23}$, Vinicius C Oliveira PhD student ${ }^{4}$, \\ Andrew J McLachlan professor ${ }^{5}$, Bart Koes professor ${ }^{6}$
}

${ }^{1}$ George Institute for Global Health, University of Sydney, PO Box M201, Camperdown, Sydney, NSW, 2050, Australia; ${ }^{2}$ Discipline of Physiotherapy, Faculty of Health Sciences, University of Sydney, Sydney; ${ }^{3}$ Faculty of Human Sciences, Macquaire University, Sydney; ${ }^{4}$ Faculty of Health Sciences, University of Sydney, Sydney; ${ }^{5}$ Faculty of Pharmacy, University of Sydney, Centre for Education and Research on Ageing, Concord Hospital, Sydney; ${ }^{6}$ Department of General Practice, Erasmus MC, University Medical Centre, Rotterdam, Netherlands

\begin{abstract}
Objective To investigate the efficacy and tolerability of analgesic and adjuvant pain drugs typically administered in primary care for the management of patients with sciatica.

Design Systematic review.

Data source International Pharmaceutical Abstracts, PsycINFO, Medline, Embase, Cochrane Central Register of Clinical Trials (CENTRAL), CINAHL, and LILACS.

Study selection Randomised controlled trials assessing the efficacy and tolerability of drugs versus placebo or other treatment for sciatica.

Data extraction Two independent reviewers extracted data and assessed methodological quality using the PEDro scale. Pain and disability outcomes were converted to a common 0 to 100 scale. Data were pooled with a random effects model, and the GRADE approach was used in summary conclusions.
\end{abstract}

Results Twenty three published reports met the inclusion criteria. The evidence to judge the efficacy of non-steroidal anti-inflammatory drugs (NSAIDs), corticosteroids, antidepressants, anticonvulsants, muscle relaxants, and opioid analgesics ranged from moderate to low quality. Most of the pooled estimates did not favour the active treatment over placebo. The pooled results of two trials of corticosteroids (mean difference in overall and leg pain $-12.2,95 \%$ confidence interval -20.9 to -3.4 ) and a single trial of the anticonvulsant gabapentin for chronic sciatica (mean difference in overall pain relief $-26.6,-38.3$ to -14.9 ) showed some benefits but only in the short term. The median rate of adverse events was $17 \%$ (interquartile range 10-30\%) for the active drugs and $11 \%(3-23 \%)$ for placebo. Trial limitations included failure to use validated outcome measures, lack of long term follow-up, and small sample size.

Conclusions As the existing evidence from clinical trials is of low quality, the efficacy and tolerability of drugs commonly prescribed for the management of sciatica in primary care is unclear.

\section{Introduction}

The clinical syndrome of sciatica has been recognised since ancient times. Currently believed to arise from a disorder of the nerve root, the syndrome is known by a range of synonyms such as lumbosacral radicular syndrome, nerve root compromise, nerve root pain, and nerve root entrapment or irritation. ${ }^{12}$ Sciatica is considered to be a prognostic indicator of poor outcome among patients with low back pain ${ }^{34}$ with a substantial proportion continuing to have persistent pain for two years or longer. ${ }^{5}$ The annual prevalence of sciatica is estimated to be between $14 \%{ }^{6}$ and $2 \%{ }^{7}$ While there are a range of definitions of sciatica, ${ }^{2}$ the key clinical features that can help clinicians to distinguish it from non-specific low back pain include unilateral leg pain that is worse than the low back pain, pain radiating below the knee, presence of numbness or pins and needles in a dermatomal distribution, positive results on a straight leg raise test, and weakness or reflex changes, or both, in a myotomal distribution. ${ }^{1}$

Analgesic and adjuvant pain drugs are often prescribed for patients with sciatica. ${ }^{8}$ Patients with a clinical diagnosis of sciatica are about five times more likely to take drugs than those with low back pain only. ${ }^{4}$ Drugs commonly prescribed for the 
management of sciatica include non-steroidal anti-inflammatory drugs (NSAIDs), skeletal muscle relaxants, opioid analgesics, benzodiazepines, systemic corticosteroids, antidepressants, and anticonvulsants. ${ }^{90}$ While guidelines provide clear and generally consistent recommendations for the prescription of drugs for non-specific low back pain, ${ }^{11}{ }^{12}$ this is not the case for sciatica. At present the efficacy and tolerability of commonly prescribed analgesic and adjuvant drugs for the management of patients with sciatica has not been established. The problem is that there are no reviews that specifically focus on these drugs that are used in primary care to manage sciatica. Because most guidelines recommend a course of conservative care before surgery is considered, it is imperative to understand what best practice conservative care should entail. In this systematic review we determined the efficacy and tolerability of analgesic and adjuvant pain drugs typically administered in primary care (orally, topically, or parentally) in the management of patients with sciatica when compared with other treatment options or no treatment.

\section{Methods}

\section{Data sources and searches}

We used the review methods advocated by the editorial board of the Cochrane Back Review Group. ${ }^{13}$ This study searched the following databases from the earliest records to 15 March 2010: International Pharmaceutical Abstracts, PsycINFO, Medline, Embase, Cochrane Central Register of Clinical Trials, CINAHL, and LILACS. Key words related to randomised controlled trial, sciatica, and drugs terms in addition to subject subheadings and word truncations specific for each database were used (see appendix on bmj.com). Electronic searches were supplemented by hand searching reference lists of eligible clinical trials. Our search was restricted to trials published in English, German, Dutch, Portuguese, and Spanish. One reviewer screened all relevant titles and abstracts and excluded clearly irrelevant papers, leaving 173 potentially relevant papers. Two reviewers independently evaluated the full reports for eligibility. Disagreements were resolved by discussion.

\section{Study selection}

Studies were eligible if they were randomised controlled trials evaluating single or any combination of analgesic or adjuvant pain drugs. For the purposes of this review, we focused on pharmacological interventions that could be administered in primary care settings, which include drugs administered via oral, topical, or parental route (that is, intramuscular injection and intravenous bolus). We excluded trials evaluating procedures that require imaging assistance and the monitoring of anaesthesia monitoring capabilities (for example, epidural, extradural, and intradiscal injections) or that require an extended period of time to be administered with monitoring of the patient's vital signs (for example, intravenous infusion). Eligible comparisons included no treatment, placebo, or other treatment options (for example, other pharmacological treatment, surgery, epidural injections, or other conservative treatment).

To be eligible studies needed to explicitly report that participants had sciatica or a synonym for sciatica. Sciatica synonyms considered included radiculopathy, nerve root compromise, nerve root compression, lumbosacral radicular syndrome, nerve root pain, nerve root entrapment, and pain radiating below the knee. The intensity or duration of symptoms was not restricted, but participants were classified as having acute (less than six weeks), subacute (six to 12 weeks), or chronic (12 weeks or more) symptoms. Trials of mixed groups of patients with low back pain were eligible if it was possible to clearly identify a subgroup with sciatica and data only from these participants were included in the analysis. There was no restriction related to the source of participants. Sciatica definitions across trials were classified as those based on clinical assessment alone and those that also require concordant imaging evidence.

Trial drugs were classified according to the Anatomical Therapeutic Chemical (ATC) classification system advocated by the World Health Organization's collaborating centre for drugs statistics methodology. ${ }^{14}$ Table 1 lists the classes of drugs and the ATC codes included in the search strategy of the original protocol $\Downarrow$.

Trials were included when one of the following outcome measures was reported: overall pain intensity (when not specified as leg or back pain), leg or back pain intensity, disability status, work status, and adverse events. We also included studies that did not report continuous data for these variables but reported percentage of improved patients. As the definition of improved (or not improved) was unclear or varied between studies, however, we did not pool these data. Work status, when identified, was listed as an outcome but pooling of these data was also not possible because of different definitions used across trials.

\section{Data extraction and quality assessment}

Two trained independent raters assessed the quality of the trials' methods using the PEDro scale. ${ }^{15}{ }^{16}$ Disagreements were resolved by a third rater. Methodological quality was not an inclusion criterion.

Two independent reviewers extracted means (final scores or change score), standard deviations, and sample sizes from studies using a standardised data extraction form. When there was insufficient information in trial reports, we contacted authors or estimated data using methods recommended in the Cochrane Handbook for Systematic Reviews of Interventions. ${ }^{17}$ Briefly, when the mean was not reported we used the median; when standard deviations could not be estimated, we adopted the standard deviation from the most similar study.

To evaluate the overall quality of the evidence and the strength of the recommendation, we used the GRADE approach. ${ }^{18} \mathrm{We}$ used an adapted version of the criteria advocated by the Cochrane Back Review Group. ${ }^{19}$ The quality of the evidence was downgraded by one level for each of four factors we encountered: limitations in the design (for instance, $>25 \%$ of participants from studies with low quality methods-PEDro score $<7$ points); inconsistency of results (for instance, $\leq 75 \%$ of the participants report findings in the same direction); and imprecision (for instance, total number of participants $<300$ for each outcome). We did not assess publication bias with funnel plots as too few studies were included in the meta-analysis. We also did not assess indirectness as this review encompasses a specific population. Two reviewers judged whether these factors were present for each outcome. Single randomised studies (with under 300 participants) were considered inconsistent and imprecise (that is, sparse data) and provided "low quality evidence." This could be further downgraded to "very low quality evidence" if there were also limitations in design. We applied the following definitions of quality of the evidence ${ }^{20}$ :

- High quality-further research is unlikely to change our confidence in the estimate of effect. There are no known or suspected reporting biases; all domains fulfilled

- Moderate quality - further research is likely to have an important impact on our confidence in the estimate of effect 
and might change the estimate; one of the domains was not fulfilled

- Low quality - further research is likely to have an important impact on our confidence in the estimate of effect and is likely to change the estimate; two of the domains were not fulfilled

- Very low quality—we are uncertain about the estimate; three of the domains were not fulfilled.

A GRADE profile was completed for each pooled estimate and for single trials comparing drugs versus placebo.

\section{Data synthesis and analysis}

Outcome data were extracted for immediate term (two or fewer weeks after randomisation), short term (more than two weeks but less than three months), intermediate term (more than three months but less than 12 months), and long term (12 months or more) follow-up evaluations. When multiple time points fell within the same category, we used the one closest to one week for the immediate term, eight weeks for the short term, six months for the intermediate term, and 12 months for the long term. Scores for pain intensity and disability were converted to a scale from 0 to 100 . When more than one outcome measure was used to assess intensity of pain, disability, or work status, we included the outcome measure described as the primary outcome measure for the trial. Descriptive statistics were used to describe adverse events reported in each trial.

Trials that we considered clinically homogeneous were grouped according to class of drugs, comparison group, dose, outcomes (pain, disability, etc), and outcome assessment time points (immediate term, short term, intermediate term, and long term). Pooled estimates were obtained with Comprehensive Meta-Analysis software, version 2.2.04 (Biostat, Englewood, NJ). Pooled effects were calculated with a random effects model. For calculation of effect size (see appendix tables A and B on bmj.com), we pooled leg pain and overall pain, as leg pain is usually worse than pain in the back. When trials were not sufficiently homogeneous, pooling of data via meta-analysis was not performed and outcome measures of the individual studies were reported. We decided a priori that a sensitivity analysis would be conducted to investigate definitions of sciatica as possible sources of heterogeneity in effect size among included studies. The limited number of trials in the meta-analysis, however, prevented further investigation.

\section{Results}

Figure 1 outlines the flow of trials through the review $\Downarrow$. The initial electronic database search identified 2460 potential studies of interest. After screening citations by title and abstract, we considered 197 potentially eligible articles for inclusion and retrieved full articles. We included 23 published reports ${ }^{21-43}$ (reporting 24 different clinical trials, as one ${ }^{28}$ reported on two trials). Three trials reported in previous systematic reviews ${ }^{12}$ 44-46 were not included in this review because of unclear randomisation. ${ }^{47-49}$

The included trials investigated six different classes of drugs: NSAIDs, antidepressants, corticosteroids, opioid analgesics, muscle relaxants, and anticonvulsants. The drugs investigated in the included trials were administered orally in 16 trials ${ }^{21-24} 27283233$ 35-38 41-43 and parenterally in five trials (four trials $^{25} 303940$ investigated intramuscular injections and one trial ${ }^{29}$ investigated intravenous infusions). Three other trials $\mathrm{s}^{263134} \mathrm{used}$ mixed administration of a starting intramuscular dose and subsequent oral doses. One study compared oral versus parenteral administration. ${ }^{22}$ Table $2 \Downarrow$ shows the characteristics of the included trials, and table $3 \Downarrow$ presents details of methodological quality.

Duration of symptoms varied a lot across studies (table $2 \Downarrow$ ). Six trials specifically investigated patients with chronic symptoms ${ }^{21} 2337384143$ and eight trials included patients with acute symptoms. $.^{22} 28-30333542$ In six trials, however, patients had mixed duration of symptoms 252734363940 ; in two trials duration was not specified ${ }^{26}{ }^{32}$; and in two trials patients were reported to have acute symptoms but no information regarding duration was provided. ${ }^{24}{ }^{31}$ Regarding the definition of sciatica, 15 trials used a definition based on clinical assessment

alone, ${ }^{21} 2324262830-35394042$ whereas nine trials also required concordant imaging evidence. $22252936-384143$ Pooling of data via meta-analysis was possible only for comparison of NSAIDs versus placebo in pain intensity at immediate follow-up and for corticosteroids versus placebo in pain intensity at immediate and short term follow-up. Table 2 also presents the number of studies comparing each class of drug and control. $\Downarrow$

\section{Placebo controlled trials}

Fifteen randomised clinical trials compared drugs with placebo with individual effect sizes calculated for nine trials (fig $2 \Downarrow$ ). For five trials investigating NSAIDs, ${ }^{31}$ corticosteroids, ${ }^{32}{ }^{34}$ antidepressants, ${ }^{21}$ and muscle relaxants,${ }^{24}$ we did not calculate effect sizes as percentage of improved patients was reported as an outcome.

\section{NSAIDS}

Four trials compared orally administered NSAIDs with placebo for acute sciatica. ${ }^{28} 3342$ Of these, three trials used a three arm design. ${ }^{28}$ Treatment effects for these studies are presented in figure $2 \Downarrow$. Data for pooling were available from all three studies. Figure $3 \Downarrow$ shows small and non-significant pooled effect size for pain (overall and leg pain) in the immediate term follow-up (mean difference $-4.9,95 \%$ confidence interval -10.2 to 0.4 ; $\mathrm{P}<0.07)$. Because of the three arm design, we calculated effect sizes for three other treatment comparisons (comparison 2 (meloxicam $7.5 \mathrm{mg} /$ day, lornoxicam $8 \mathrm{mg}$ /day, piroxicam 20 $\mathrm{mg} /$ day $v$ placebo): mean difference $-4.4,-8.9$ to $0.1, \mathrm{I}^{2}=0.1 \%$, $\mathrm{P}<0.06$; comparison 3 (meloxicam $15 \mathrm{mg} /$ day, lornoxicam 8 $\mathrm{mg}$ /day, piroxicam $2 \mathrm{mg} /$ day $v$ placebo): mean difference -3.9 , -8.0 to $0.2, \mathrm{I}^{2}=0.6 \%, \mathrm{P}<0.07$; comparison 4 (meloxicam 15 $\mathrm{mg}$ /day, diclofenac 50-150 mg/day, piroxicam $20 \mathrm{mg} /$ day $v$ placebo): mean difference $-4.4,-9.4$ to $0.6, \mathrm{I}^{2}=6.8 \%, \mathrm{P}<0.09$ ) (not shown in fig 3). The quality of evidence (GRADE) for this pooling was rated "low quality" (downgraded for limitation of study design and inconsistency).

\section{Corticosteroids}

Three trials in patients with acute sciatica tested the effect of corticosteroids compared with placebo. ${ }^{29}{ }^{30} 35$ The individual studies provided imprecise estimates of treatment effect (fig $2 \Downarrow)$. For the immediate term, pooling showed no effect of steroids on leg pain (mean difference $-1.8,-11.1$ to $7.5 ; \mathrm{P}=0.71$ ) with a GRADE classification of "moderate quality" of evidence (downgraded for imprecision) (fig $3 \Downarrow$ ). For the short term, pooling showed a significant effect of steroids on pain (overall and leg pain) (mean difference $-12.2,-20.9$ to $-3.4 ; \mathrm{P}<0.01$ ) and "moderate quality" of evidence according to the GRADE approach (downgraded for imprecision) (fig $3 \Downarrow$ ). 


\section{Antidepressants, anticonvulsants, and opioid analgesics}

Three trials investigated the efficacy of antidepressants, anticonvulsants, and opioid analgesics (fig $2 \Downarrow$ ). ${ }^{37} 3843$ As these were single trials that investigated different classes of drugs or time points of assessment, pooling was not possible. Hence, the quality of evidence for all these medications was considered "low quality" (single studies) 37 $^{43}$ or "very low quality" (single study downgraded for limitation of study design) ${ }^{38}$ according to the GRADE approach.

Two trials investigated the effect of anticonvulsants in patients with chronic symptoms of sciatica. In one crossover trial, ${ }^{38}$ topiramate (50-400 mg/day) showed no better immediate effects than placebo for disability and leg or back pain. In contrast, data from another trial ${ }^{43}$ showed significant overall pain relieving effect with the anticonvulsant gabapentin $(900-3600 \mathrm{mg})$ in the short term (mean difference $-26.6,-38.3$ to $-14.9 ; \mathrm{P}<0.001$ ) compared with placebo.

One crossover study with four periods investigated the relative efficacy of opioid analgesics (sustained release morphine 15 $\mathrm{mg}$ /day), antidepressants (nortriptyline $25 \mathrm{mg}$ /day), and a combination of both and placebo in patients with chronic sciatica. ${ }^{37}$ In this trial, antidepressants, opioid analgesics, and a combination of both had no significant effect compared with placebo in the immediate term for disability or leg or back pain.

\section{NSAIDs $v$ NSAIDs}

Five studies compared one type of NSAID with other NSAIDs. ${ }^{25} 283339{ }^{40}$ Figure $4 \Downarrow$ shows all the comparisons involving different types of NSAIDs. None of these studies showed one NSAID to be better than the other. One study found no difference in overall pain between oral and parenteral administration of meloxicam $15 \mathrm{mg}$ a day. ${ }^{22}$

\section{NSAIDs $v$ other treatments}

In three separate trials the NSAID diclofenac (50-75 mg/day) showed no difference in outcomes compared with antidepressant ${ }^{36}$ or electroacupuncture ${ }^{41}$ but did worse than caudal epidural injections of corticosteroids ${ }^{27}$ for pain and disability, specifically in the immediate follow-up (fig $3 \Downarrow$ ). In one trial the NSAID ketoprofen ( $200 \mathrm{mg} /$ day) was no better than a combination of corticosteroids for pain in the immediate follow-up. ${ }^{26}$

\section{Adverse events}

Adverse events were investigated in $75 \%$ (18/24) of the included trials (table $4 \Downarrow$ ); the median number of adverse events (interquartile range) was $17 \%(10-30 \%)$ for the active drugs and $11 \%$ (3-23\%) for placebo. The rate and type of adverse events reported varied substantially between drugs and between trials for the same medicine.

\section{Discussion}

There is at best only low quality evidence to judge the efficacy and tolerability of drugs commonly prescribed for the management of sciatica in primary care. The available evidence does not clearly show favourable effects of NSAIDs, corticosteroids, antidepressants, or opioid analgesics in the immediate term, even compared with placebo. Evidence from a single trial and one meta-analysis with two trials provides some limited support ("low quality" and "moderate quality" evidence) for the use of NSAIDs and corticosteroids to relieve pain in the short term in patients with acute sciatica. In one small sample trial there was also limited support ("low quality" evidence) for the short term relief of pain in chronic sciatica with an anticonvulsant drug. At present these data provide a lack of conclusive and high quality evidence to guide the prescription of these drugs for patients with sciatica in primary care.

\section{Strengths and limitations of review}

The strengths of this systematic review include the use of a prespecified protocol, inclusion of trials published in languages other than English, and the use of a highly sensitive search strategy to identify trials for sciatica coupled with search terms related to the nine classes of drugs of interest. We assessed methodological quality with the PEDro scale rather than the Cochrane Risk of Bias tool because the PEDro scale has been shown to have acceptable reliability ${ }^{16}$ and validity, ${ }^{150}$ whereas two studies have reported reliability limitations with the Cochrane tool. ${ }^{51}{ }^{52}$ One limitation of our study is the possibility of publication bias as we did not attempt to identify unpublished trials that could be found in clinical trials registries and conference proceedings. Another limitation is that we could accommodate trials in only four languages other than English.

A strength of our review over past reviews is that we located 24 randomised clinical trials relevant to our question compared with six, ${ }^{12}$ three, ${ }^{46}$ and two ${ }^{44} 45$ trials included in the four previous reviews. Accordingly we provide more precise estimates of treatment effects, specifically for NSAIDs and corticosteroids, and a better description about tolerability of all classes of drug. Including more trials has allowed us to provide a more in-depth evaluation of the pharmacological treatments that have been tested for sciatica in primary care. For example, we have provided information on the efficacy of antidepressants and opioid analgesics whereas previous reviews did not cover these classes of drugs. Another strength of this review is that we quantitatively pooled trials where possible. This allowed us to explore the size of the treatment effect, which is not possible in a qualitative summary. In addition, we were able to assess the overall quality of the evidence with the GRADE approach. Although conclusions of previous reviews were based on a surprising paucity of evidence, our findings are likely to inform the direction of future research in this topic. In pharmacological trials for sciatica, we consider the priorities to include consideration of duration of symptoms, recruitment of large samples, and collection of outcomes relevant to patients. For instance, regarding duration of symptoms it would be reasonable to test corticosteroids and NSAIDs in trials in patients with acute sciatica, whereas given that chronic sciatica includes a neuropathic pain component, anticonvulsant and antidepressants might need to be tested in patients with a chronic condition.

Although the knowledge of evidence about surgery has changed in the past decade, we still do not know much about a simpler conservative treatment such as pharmacological interventions for sciatica. A recent clinical practice guideline from the American Pain Society ${ }^{53}$ recommends that surgery should be considered as a treatment option for persistent and disabling radicular pain caused by a herniated lumbar disc. This recommendation relies on moderate short term benefits from large randomised clinical trials such as those by Peul et $\mathrm{al}^{5455}$ and Weinstein et al, ${ }^{56}$ with 283 and 501 patients randomised, respectively. At present, there is a limited number of mainly small trials of pharmacological interventions with typically short term follow-up. For example, the evidence to support the use of anticonvulsants in chronic sciatica arises from a single trial with only 50 participants. 
Our principal finding is that there is insufficient evidence to confidently guide the use of any analgesic or adjuvant pain medicine for the effective management of pain and disability in patients with sciatica. Until this changes, we would advise clinicians treating such patients who exhibit clinical features of neuropathic pain to consider evidence based guidelines for neuropathic pain $^{57-59}$ and for other patients with sciatica to consider therapeutic recommendations from current guidelines for the management of non-specific low back pain. ${ }^{11}$

Contributors: RZP, CGM, BK, PHF, MLF, MH, and AJM were involved in the design of the review. RZP, MLF, PHF, and VCO developed the search strategy and performed the study selection. RZP, MH, AJM, and VCO extracted data from included studies. RZP, CGM, BK, AJM, and VCO were involved in data analysis. RZP, CGM, BK, PHF, MLF, and $\mathrm{MH}$ were involved in the interpretation and discussion of results. All authors contributed to the writing and review of the various drafts of the report. RZP and CGM are guarantors.

Funding: This research received no specific grant from any funding agency in the public, commercial, or not-for-profit sectors. RZP is supported by Capes Foundation, Ministry of Education of Brazil. CGM is supported by a research fellowship funded by the Australian Research Council.

Competing interests: All authors have completed the ICMJE uniform disclosure form at www.icmje.org/coi_disclosure.pdf (available on request from the corresponding author) and declare: no support from any organisation for the submitted work; no financial relationships with any organisations that might have an interest in the submitted work in the previous three years; no other relationships or activities that could appear to have influenced the submitted work.

Ethical approval: Nor required.

Data sharing: No additional data available.

Koes BW, van Tulder MW, Peul WC. Diagnosis and treatment of sciatica. BMJ 2007;334:1313-7.

2 Konstantinou K, Dunn KM. Sciatica: review of epidemiological studies and prevalence estimates. Spine 2008:33:2464-72.

3 Balague F, Nordin M, Sheikhzadeh A, Echegoyen AC, Brisby H, Hoogewoud HM, et al. Recovery of severe sciatica. Spine 1999;24:2516-24.

4 Selim AJ, Ren XS, Fincke G, Deyo RA, Rogers W, Miller D, et al. The importance of radiating leg pain in assessing health outcomes among patients with low back pain. Results from the Veterans' Health Study. Spine 1998;23:470-4.

5 Tubach F, Beaute J, Leclerc A. Natural history and prognostic indicators of sciatica. J Clin Epidemiol 2004;57:174-9.

6 Palmer KT, Griffin MJ, Syddall HE, Pannett B, Cooper C, Coggon D. The relative importance of whole body vibration and occupational lifting as risk factors for low-back pain. Occup Environ Med 2003;60:715-21.

7 Younes M, Bejia I, Aguir Z, Letaief M, Hassen-Zrour S, Touzi M, et al. Prevalence and risk factors of disk-related sciatica in an urban population in Tunisia. Joint Bone Spine 2006:73:538-42.

8 Vogt MT, Kwoh CK, Cope DK, Osial TA, Culyba M, Starz TW. Analgesic usage for low back pain: impact on health care costs and service use. Spine 2005;30:1075-81.

9 Cherkin DC, Wheeler KJ, Barlow W, Deyo RA. Medication use for low back pain in primary care. Spine 1998;23:607-14

10 Di lorio D, Henley E, Doughty A. A survey of primary care physician practice patterns and adherence to acute low back problem guidelines. Arch Fam Med 2000;9:1015-21.

11 Koes BW, van Tulder M, Lin CW, Macedo LG, McAuley J, Maher C. An updated overview of clinical guidelines for the management of non-specific low back pain in primary care. Eur Spine J 2010;19:2075-94

12 Chou R, Huffman LH. Medications for acute and chronic low back pain: a review of the evidence for an American Pain Society/American College of Physicians clinical practice guideline. Ann Intern Med 2007;147:505-14.

13 Furlan AD, Pennick V, Bombardier C, van Tulder M. 2009 updated method guidelines for systematic reviews in the Cochrane Back Review Group. Spine 2009;34:1929-41.

14 WHO Collaborating Centre for Drugs Statistics Methodology. International language for drug utilisation research. 2011. www.whocc.no/.

15 Macedo LG, Elkins MR, Maher CG, Moseley AM, Herbert RD, Sherrington C. There was evidence of convergent and construct validity of Physiotherapy Evidence Database quality scale for physiotherapy trials. J Clin Epidemiol 2010;63:920-5.

16 Maher CG, Sherrington C, Herbert RD, Moseley AM, Elkins M. Reliability of the PEDro scale for rating quality of randomized controlled trials. Phys Ther 2003;83:713-21.

17 Higgins JPT, Green S. Cochrane handbook for systematic reviews of interventions, version 5.0.2. Cochrane Collaboration, 2009.

18 Atkins D, Best D, Briss PA, Eccles M, Falck-Ytter Y, Flottorp S, et al. Grading quality of evidence and strength of recommendations. BMJ 2004;328:1490.

19 Henschke N, Ostelo RW, van Tulder MW, Vlaeyen JW, Morley S, Assendelft WJ, et al. Behavioural treatment for chronic low-back pain. Cochrane Database Syst Rev 2010;7:CD002014.
20 Guyatt GH, Oxman AD, Vist GE, Kunz R, Falck-Ytter Y, Alonso-Coello P, et al. GRADE: an emerging consensus on rating quality of evidence and strength of recommendations. BMJ 2008:336:924-6.

21 Atkinson J, Slater MA, Williams RA, Zisook S, Patterson TL, Grant I, et al. A placebo-controlled randomized clinical trial of nortriptyline for chronic low back pain. Pain 1998;76:287-96.

22 Auvinet B, Ziller R, Appelboom T, Velicitat P. Comparison of the onset and intensity of action of intramuscular meloxicam and oral meloxicam in patients with acute sciatica. Clin Ther 1995; 17:1078-98

23 Baron R, Freynhagen R, Tolle TR, Cloutier C, Leon T, Murphy TK, et al. The efficacy and safety of pregabalin in the treatment of neuropathic pain associated with chronic lumbosacral radiculopathy. Pain 2010;150:420-7.

24 Berry $\mathrm{H}$, Hutchinson DR. A multicentre placebo-controlled study in general practice to evaluate the efficacy and safety of tizanidine in acute low-back pain. $J$ Int Med Res 1988:16:75-82.

25 Borms T. Comparison of injectable formulations of tiaprofenic acid and ketoprofen in acute lumbar sciatica. Single-blind randomised trial. Drugs 1988;35:85-7.

26 Braun H, Huberty R. [Therapy of lumbar sciatica. A comparative clinical study of a corticoid-free monosubstance and a corticoid-containing combination drug.] Med Welt 1982;33:490-1.

27 Dincer U, Kiralp MZ, Cakar E, Yasar E, Dursan H. Caudal epidural injection versus non-steroidal anti-inflammatory drugs in the treatment of low back pain accompanied with radicular pain. Joint Bone Spine 2007;74:467-71

28 Dreiser RL, Le Parc JM, Velicitat P, Lleu PL. Oral meloxicam is effective in acute sciatica: two randomised, double-blind trials versus placebo or diclofenac. Inflamm Res 2001;50:S17-23.

29 Finckh A, Zufferey P, Schurch MA, Balague F, Waldburger M, So AK. Short-term efficacy of intravenous pulse glucocorticoids in acute discogenic sciatica. A randomized controlled trial. Spine 2006;31:377-81

30 Friedman BW, Esses D, Solorzano C, Choi HK, Cole M, Davitt M, et al. A randomized placebo-controlled trial of single-dose IM corticosteroid for radicular low back pain. Spine 2008;33:e624-9.

31 Grevsten $\mathrm{S}$, Johansson $\mathrm{H}$. Phenylbutazone in treatment of acute lumbago-sciatica. $Z$ Rheumatol 1975;34:444-7.

32 Haimovic IC, Beresford HR. Dexamethasone is not superior to placebo for treating lumbosacral radicular pain. Neurology 1986;36:1593-4.

33 Herrmann WA, Geertsen MS. Efficacy and safety of lornoxicam compared with placebo and diclofenac in acute sciatica/lumbo-sciatica: an analysis from a randomised, double-blind, multicentre, parallel-group study. Int J Clin Pract 2009:63:1613-21.

34 Hofferberth B, Gottschaldt M, Grass H, Buttner K. [The usefulness of dexamethasonephosphate in the conservative treatment of lumbar pain-a double-blind study (author's translation).] Arch Psychiatr Nervenkr 1982;231:359-67.

35 Holve RL, Barkan H. Oral steroids in initial treatment of acute sciatica. J Am Board Fam Med 2008:21:469-74.

36 Kanayama M, Hashimoto $\mathrm{T}$, Shigenobu K, Oha F, Yamane S. New treatment of lumbar disc herniation involving 5-hydroxytryptamine2A receptor inhibitor: a randomized controlled trial. J Neurosurg Spine 2005;2:441-6.

37 Khoromi S, Cui L, Nackers L, Max MB. Morphine, nortriptyline and their combination vs placebo in patients with chronic lumbar root pain. Pain 2007;130:66-75.

38 Khoromi S, Patsalides A, Parada S, Salehi V, Meegan JM, Max MB. Topiramate in chronic lumbar radicular pain. J Pain 2005:6:829-36.

39 Rachid A. Avaliação da eficácia e tolerância do cetoprofeno (200 mg/dia) comparada ao diclofenac sódico ( $150 \mathrm{mg} / \mathrm{dia}$ ) no tratamento da lombociatalgia aguda. [Evaluation of efficacy and safety of ketoprofen $(200 \mathrm{mg} /$ day $)$ compared to diclofenac $(150 \mathrm{mg} /$ day $)$ in the treatment of acute lombociatalgia.] Rev Bras Med 1992;49:37-40.

40 Schuermans $Y$, Rauis A. Comparative clinical trial of two injectable NSAIDs, tiaprofenic acid and alclofenac, in acute sciatica. Drugs 1988:35(suppl 1):83-5.

41 Wang BX, La JL. Therapeutic effects of electro-acupuncture and diclofenic on herniation of lumbar intervertebral disc. Zhongguo Linchuang Kangfu 2004;8:3413-5.

42 Weber $\mathrm{H}$, Holme I, Amlie E. The natural course of acute sciatica with nerve root symptoms in a double-blind placebo-controlled trial evaluating the effect of piroxicam. Spine 1993;18:1433-8.

43 Yildirim K, Sisecioglu M, Karatay S, Erdal A, Levent A, Ugur M, et al. The effectiveness of gabapentin in patients with chronic radiculopathy. Pain Clinic 2003;15:213-8.

44 Luijsterburg PA, Verhagen AP, Ostelo RW, van Os TA, Peul WC, Koes BW. Effectiveness of conservative treatments for the lumbosacral radicular syndrome: a systematic review. Eur Spine J 2007;16:881-99.

45 Roelofs PDDM, Deyo RA, Koes BW, Scholten RJPM, van Tulder MW. Non-steroidal anti-inflammatory drugs for low back pain. Cochrane Database Syst Rev 2010;1:CD000396.

46 Vroomen PC, de Krom MC, Slofstra PD, Knottnerus JA. Conservative treatment of sciatica: a systematic review. J Spinal Disord 2000;13:463-9.

47 Goldie I. A clinical trial with indomethacin (indomee(R)) in low back pain and sciatica. Acta Orthop Scand 1968;39:117-28.

48 Radin EL, Bryan RS. Phenylbutazone for prolapsed discs? Lancet 1968;2:736.

49 Weber $\mathrm{H}$, Aasand $\mathrm{G}$. The effect of phenylbutazone on patients with acute lumbago-sciatica. A double blind trial. J Oslo City Hosp 1980;30:69-72.

50 De Morton NA. The PEDro scale is a valid measure of the methodological quality of clinical trials: a demographic study. Aust $J$ Physiother 2009;55:129-33.

51 Armijo-Olivo S, Stiles CR, Hagen NA, Biondo PD, Cummings GG. Assessment of study quality for systematic reviews: a comparison of the Cochrane Collaboration Risk of Bias Tool and the Effective Public Health Practice Project Quality Assessment Tool: methodological research. J Eval Clin Pract 2012;18:1218.

52 Hartling L, Ospina M, Liang Y, Dryden DM, Hooton N, Krebs Seida J, et al. Risk of bias versus quality assessment of randomised controlled trials: cross sectional study. $B M J$ 2009;339:b4012.

53 Chou R, Loeser JD, Owens DK, Rosenquist RW, Atlas SJ, Baisden J, et al. Interventional therapies, surgery, and interdisciplinary rehabilitation for low back pain: an evidence-based clinical practice guideline from the American Pain Society. Spine 2009:34:1066-77.

54 Peul WC, van den Hout WB, Brand R, Thomeer RT, Koes BW. Prolonged conservative care versus early surgery in patients with sciatica caused by lumbar disc herniation: two year results of a randomised controlled trial. BMJ 2008;336:1355-8.

55 Peul WC, van Houwelingen HC, van den Hout WB, Brand R, Eekhof JA, Tans JT, et al. Surgery versus prolonged conservative treatment for sciatica. $N$ Engl J Med 2007;356:2245-56. 


\section{What is already known on this topic}

Pain relieving drugs are often prescribed by general practitioners for patients with sciatica

While guidelines provide clear and generally consistent recommendations for the prescription of drugs for non-specific low back pain, this is not the case for sciatica

The efficacy and tolerability of drugs in the management of sciatica administered in primary care has not been established

\section{What this study adds}

There is low quality evidence for the efficacy of NSAIDs, corticosteroids, and anticonvulsants

The available evidence does not clearly show favourable effects of NSAIDs, corticosteroids, antidepressants, muscle relaxants, and opioid analgesics in the immediate term and provides limited support for the use of NSAIDs, corticosteroids, and anticonvulsants in the short term

At present these data provide a lack of conclusive and high quality evidence to endorse the prescription of these drugs for patients with sciatica in primary care

56 Weinstein JN, Tosteson TD, Lurie JD, Tosteson AN, Hanscom B, Skinner JS, et al. Surgical vs nonoperative treatment for lumbar disk herniation: the Spine Patient Outcomes Research Trial (SPORT): a randomized trial. JAMA 2006;296:2441-50.

57 Dworkin RH, O'Connor AB, Audette J, Baron R, Gourlay GK, Haanpaa ML, et al. Recommendations for the pharmacological management of neuropathic pain: an overview and literature update. Mayo Clin Proc 2010;85:S3-14.

58 National Institute for Health and Clinical Excellence. Neuropathic pain: the pharmacological management of neuropathic pain in adults in non-specialist settings. Clinical guideline 96. 2011. www.nice.org.uk/CG96.

59 Tan T, Barry P, Reken S, Baker M. Pharmacological management of neuropathic pain in non-specialist settings: summary of NICE guidance. BMJ 2010;340:c1079.
Accepted: 21 November 2011

\section{Cite this as: BMJ 2012:344:e497}

This is an open-access article distributed under the terms of the Creative Commons Attribution Non-commercial License, which permits use, distribution, and reproduction in any medium, provided the original work is properly cited, the use is non commercial and is otherwise in compliance with the license. See: http://creativecommons.org/licenses/bync/2.0/ and http://creativecommons.org/licenses/by-nc/2.0/legalcode. 


\section{Tables}

Table 1 | Classes of drugs and Anatomical Therapeutic Chemical (ATC) codes included in search strategy

ATC code

Analgesics:

\begin{tabular}{lc}
\hline Any & N02 \\
\hline Opioid analgesics & N02A \\
\hline Paracetamol & N02BE01 \\
\hline Anticonvulsants (or antiepileptics) & N03 \\
\hline Antidepressants & N06A \\
\hline Benzodiazepine derivatives & N05BA \\
\hline Corticosteroids for systemic use & H02 \\
\hline Non-steroidal anti-inflammatory drugs & M01A \\
\hline Skeletal muscle relaxants & M03
\end{tabular}




\begin{tabular}{|c|c|c|c|}
\hline Study & Details of participants & Interventions (dose regimens and dosing duration) & $\begin{array}{l}\text { Outcomes (measures) and time } \\
\text { points }\end{array}$ \\
\hline \multicolumn{4}{|l|}{ NSAID $v$ placebo } \\
\hline Grevsten $1975^{31}$ & $\begin{array}{l}\text { Source: outpatient department of surgical or } \\
\text { surgical-orthopaedic clinic; } n=36 \text {; group } 1=18 \text {, } \\
\text { group } 2=18 \text {; age: } 23-62 \text {; duration: acute (NS) }\end{array}$ & $\begin{array}{l}\text { Group 1: IM phenylbutazone }(0.6 \mathrm{~g} \text { ) on day } 1 \text {, oral dose } 0.2 \\
\mathrm{g} \text { (two tablets) on days } 2-4 \text {, oral dose } 0.1 \mathrm{~g} \text { (one tablet) in } \\
\text { days } 5-15 \mathrm{v} \text { group } 2 \text { : IM distilled water, } \mathrm{NaOH} 1 \mathrm{~N} \text { to } \mathrm{pH} 8 \text { ( } 0.6 \\
\mathrm{~g} \text { ) on day } 1 \text {, oral dose } 0.2 \mathrm{~g} \text { (two tablets) on days } 2-4 \text {, oral } \\
\text { dose } 0.1 \mathrm{~g} \text { (one tablet) on days } 5-15 \text {. Additional analgesics } \\
\text { allowed }\end{array}$ & $\begin{array}{l}\% \text { of improved patients; adverse } \\
\text { events; at two weeks }\end{array}$ \\
\hline Weber $1993^{42}$ & $\begin{array}{l}\text { Source: patients recruited from practitioners } \\
\text { and company doctors; } n=208 \text {; group } 1=120 \text {, } \\
\text { group } 2=94 \text {; age }=48 \text { (SD NS); duration: acute } \\
\text { (onset of pain within } 14 \text { days) }\end{array}$ & $\begin{array}{l}\text { Group 1: } 20 \mathrm{mg} \text { oral piroxicam } v \text { group } 2 \text { : oral placebo. Twice } \\
\text { daily for first two days, followed by once daily for next } 12 \text { days. } \\
\text { Additional analgesics allowed }\end{array}$ & $\begin{array}{l}\text { Leg and back pain ( } 0-100 \text { scale); } \\
\text { disability (RM); adverse events; } \\
\text { work status } \\
\text { (no/sometimes/often); at } 1,2,3 \text {, } \\
\text { and } 4 \text { weeks }\end{array}$ \\
\hline \multicolumn{4}{|l|}{ Dreisser $2001^{28}:$} \\
\hline $\begin{array}{l}\text { Placebo control } \\
\text { study }\end{array}$ & $\begin{array}{l}\text { Source: } 79 \text { centres in } 6 \text { countries; } n=532 ; \text { group } \\
1=117 \text { (mean (SD) age } 47(14)) \text {, group } 2=181 \\
(47(15)) \text {, group } 3=180(47(14)) \text {; duration: } \\
\text { acute (onset of pain within } 3 \text { days) }\end{array}$ & $\begin{array}{l}\text { Group 1: } 7.5 \mathrm{mg} \text { oral meloxicam } v \text { group } 2: 15 \mathrm{mg} \text { oral } \\
\text { meloxicam } v \text { group 3: oral placebo. Once daily for } 7 \text { days }\end{array}$ & \multirow[t]{2}{*}{$\begin{array}{l}\text { Overall pain (0-100 scale); } \\
\text { adverse events; day } 3 \text { and day } \\
7\end{array}$} \\
\hline $\begin{array}{l}\text { Diclofenac } \\
\text { control study }\end{array}$ & $\begin{array}{l}\text { Source: } 117 \text { centres in } 10 \text { countries; } n=489 \text {; } \\
\text { group } 1=164 \text { (mean (SD) age } 46(14)) \text {, group } \\
2=163 \text { ( } 45(14) \text { ), group } 3=162(44(13)) \text {; } \\
\text { duration: acute (onset of pain within } 3 \text { days) }\end{array}$ & $\begin{array}{l}\text { Group } 1: 7.5 \mathrm{mg} \text { oral meloxicam once daily } v \text { group } 2: 15 \mathrm{mg} \\
\text { oral meloxicam once daily } v \text { group } 3: 50 \mathrm{mg} \text { oral diclofenac } \\
\text { three times daily for } 14 \text { days. Additional analgesics allowed } \\
\text { in both studies }\end{array}$ & \\
\hline Herrmann $2009^{33}$ & $\begin{array}{l}\text { Source: outpatients from general practices; } \\
\mathrm{n}=171 ; \text { group } 1=57 \text { (mean (SD) age } 52(15)) \\
\text { group } 2=57(49(14)) \text {, group } 3=57(48(12)) \\
\text { duration: acute (onset of pain within } 3 \text { days) }\end{array}$ & $\begin{array}{l}\text { Group } 1: 8 \mathrm{mg} \text { oral lornoxicam } \times 2 \text { on day } 1 \text { (loading dose) }+1 \\
\text { capsule after } 8 \text { hours, twice daily on day } 2-4 \text {, once on day } 5 \text {; } \\
v \text { group } 2: 50 \mathrm{mg} \text { oral diclofenac one/day on day } 1,3 \text { times/day } \\
\text { on days } 2-4 \text {, once on day } 5 \text { (optional) } v \text { group } 3 \text { : oral placebo } \\
\text { (capsules added to group } 1 \text { and group } 2 \text { blister packs) }\end{array}$ & $\begin{array}{l}\text { Overall pain (0-100 scale), } \\
\text { adverse events, at } 3,4,6 \text {, and } 8 \\
\text { hours }\end{array}$ \\
\hline \multicolumn{4}{|c|}{ Corticosteroids $v$ placebo } \\
\hline Hofferberth $1982^{34}$ & $\begin{array}{l}\text { Source: NS; } n=91 ; \text { group } 1=38, \text { group } 2=53 \text {; } \\
\text { age: } 47 \text { (range } 30-70) ; \text { duration: } \text { mixed }(>1 \\
\text { month) }\end{array}$ & $\begin{array}{l}\text { Group 1: IM dexamethasone ( } 168 \mathrm{mg}) v \text { group } 2 \text { : IM placebo; } \\
2 \text { ampoules } 3 \text { times/day on day } 1-5 \text {, one ampoule } 3 \text { times/day } \\
\text { on days } 6-8 \text {, one ampoule twice on day } 9 \text {, one ampoule on } \\
\text { day } 10 \text {. Additional analgesics and physiotherapy were allowed }\end{array}$ & $\begin{array}{l}\% \text { of improved patients at } 11 \\
\text { days, } 6 \text { weeks, and } 6 \text { months }\end{array}$ \\
\hline Haimovic $1986^{32}$ & $\begin{array}{l}\text { Source: NS; } n=33 \text {; group } 1=21 \text {, group } 2=12 \text {; } \\
\text { age: NS; duration: NS }\end{array}$ & $\begin{array}{l}\text { Group 1: oral dexamethasone } v \text { group } 2 \text { : oral placebo; } 64 \mathrm{mg} \\
\text { on day } 1,32 \mathrm{mg} \text { on day } 2,16 \mathrm{mg} \text { on day } 3,12 \mathrm{mg} \text { on day } 4 \text {, } \\
8 \mathrm{mg} \text { on days } 5-7 \text {. Additional analgesics allowed and } \\
\text { participants kept on bed rest for } 7 \text { days of treatment }\end{array}$ & $\begin{array}{l}\% \text { of improved patients at } 7 \text { days } \\
\text { and } 12 \text { months }\end{array}$ \\
\hline Finckh $2006^{29}$ & $\begin{array}{l}\text { Source: university and non-university hospitals; } \\
\mathrm{n}=60 \text {; group } 1=31 \text { (mean (SD) age } 49(18)) \\
\text { group } 2=29(45(13)) \text {; duration: acute }(>1 \text { week } \\
\text { to }<6 \text { weeks) }\end{array}$ & $\begin{array}{l}\text { Group 1: single IV infusion bolus of } 500 \mathrm{mg} \\
\text { methylprednisolone } v \text { group } 2 \text { : single intravenous infusion of } \\
0.9 \% \text { saline; additional analgesics, NSAIDs, glucocorticoids, } \\
\text { and physical therapy allowed }\end{array}$ & $\begin{array}{l}\text { Leg pain (0-100 scale), adverse } \\
\text { events, on days } 1-3 \text { and day } 10\end{array}$ \\
\hline Holve $2008^{35}$ & $\begin{array}{l}\text { Source: primary care or emergency } \\
\text { departments; } n=29 ; \text { group } 1=15 \text { (age } 39(95 \% \\
\text { Cl } 33 \text { to } 46) \text {, group } 2=14 \text { ( } 43 \text { ( } 38 \text { to } 46)) \text {; } \\
\text { duration: acute (onset of pain within } 1 \text { week) }\end{array}$ & $\begin{array}{l}\text { Group 1: oral prednisolone ( } 60 \mathrm{mg} / \text { day for three days, } 40 \\
\mathrm{mg} / \text { day for } 3 \text { days, and } 20 \mathrm{mg} / \mathrm{day} \text { for } 3 \text { days) } v \text { group } 2 \text { : oral } \\
\text { placebo (containing inert filler substance); daily oral } \\
\text { administration } 60 \mathrm{mg} \text { on days } 1-3,40 \mathrm{mg} \text { on days } 4-9,20 \mathrm{mg} \\
\text { on days } 7-9 . \text { Additional analgesics allowed and, if needed; } \\
\text { activity as tolerated; and referral to physical therapy }\end{array}$ & $\begin{array}{l}\text { Pain ( } 0-5 \text { scale), disability (ODI), } \\
\text { adverse events, work status (No } \\
\text { of hours patients was employed), } \\
\text { at } 1,2,3 \text {, and } 4 \text { weeks, and } 2,3 \text {, } \\
4,5 \text {, and } 6 \text { months }\end{array}$ \\
\hline Friedman $2008^{30}$ & $\begin{array}{l}\text { Source: teaching hospital; } n=82 ; \text { group } 1=39 \\
\text { (mean (SD) age } 39(9)) \text {, group } 2=43(37(8) ; \\
\text { duration: acute ( } \leq 7 \text { days) }\end{array}$ & $\begin{array}{l}\text { Group 1: IM methylprednisolone }(160 \mathrm{mg}) v \text { group } 2 \text { : IM } \\
\text { placebo. Additional analgesics, opioid analgesics, and NSAIDs } \\
\text { allowed }\end{array}$ & $\begin{array}{l}\text { Overall pain (0-10 scale), } \\
\text { adverse events. Work status (rate } \\
\text { of return to work), at } 1 \text { month }\end{array}$ \\
\hline \multicolumn{4}{|c|}{ Antidepressant $v$ placebo } \\
\hline Atkinson $1998^{21}$ & $\begin{array}{l}\text { Source: university medical primary care centre, } \\
\text { orthopaedic clinic, and local community; } n=15 \text {; } \\
\text { group } 1=6 \text { (mean (SD) age } 46(11)) \text {, group } 2=9 \\
(47(11)) \text {; duration: chronic ( } \geq 6 \text { months) }\end{array}$ & $\begin{array}{l}\text { Group 1: oral nortriptyline } v \text { group } 2 \text { : oral doses of placebo. } \\
\text { Both groups received identical capsules: } 25 \mathrm{mg} / \text { day for } 3 \text { days; } \\
50 \mathrm{mg} / \text { day for } 4 \text { days, } 75 \mathrm{mg} \text { for } 3 \text { days, and } 100 \mathrm{mg} / \text { day for } \\
4 \text { days. Additional analgesics allowed }\end{array}$ & $\begin{array}{l}\% \text { of improved patients at } 8 \\
\text { weeks }\end{array}$ \\
\hline \multicolumn{4}{|c|}{ Anticonvulsant $v$ placebo } \\
\hline Yildirim $2003^{43}$ & $\begin{array}{l}\text { Source: outpatient setting; } \mathrm{n}=50 ; \text { group } 1=25 \\
\text { (mean }(\mathrm{SD}) \text { age } 38(7)) \text {, group } 2=25(41(11)) ; \\
\text { duration: chronic (group } 1=69.3(3-180) \\
\text { months, group } 2=67.7(5-240) \text { months) }\end{array}$ & $\begin{array}{l}\text { Group 1: oral gabapentin } 900-3600 \text { mg divided in } 3 \text { doses on } \\
\text { day } 1 \text { depending on tolerability } v \text { group } 2 \text { : oral placebo } 3 / \text { day } \\
\text { for } 8 \text { weeks }\end{array}$ & $\begin{array}{l}\text { Overall pain ( } 0-3 \text { scale), adverse } \\
\text { events, at } 1 \text { and } 2 \text { months }\end{array}$ \\
\hline
\end{tabular}


Table 2 (continued)

\begin{tabular}{|c|c|c|}
\hline Study & Details of participants & Interventions (dose regimens and dosing duration) \\
\hline $\begin{array}{l}\text { Khoromi } 2005^{38} \\
\text { (cross over) }\end{array}$ & $\begin{array}{l}\text { Source: recruited through local newspaper } \\
\text { advertisements; } n=29 \text {; age: } 53 \text { (28-74); } \\
\text { duration: chronic (>3 months) }\end{array}$ & $\begin{array}{l}\text { Group 1: oral topiramate } 50 \mathrm{mg} \text { in } 2 \text { divided doses in week } 1 \text {, } \\
50 \mathrm{mg} \text { increments in each morning and night doses to } \\
\text { maximum of } 400 \mathrm{mg} \text { in weeks } 2-4 \mathrm{v} \text { group } 2 \text { : oral doses of } \\
\text { diphenhydramine (placebo) } 6.25 \mathrm{mg} \text { twice/day in week } 1 \text {, } \\
\text { increased by } 6.25 \mathrm{mg} \text { increments in each dose in week } 2 \text {, } \\
\text { increased by } 12.5 \mathrm{mg} \text { increments in each dose in week } 3 \text { to } \\
\text { maximum of } 50 \mathrm{mg} / \text { day in } 2 \text { divided doses. Each period } \\
\text { consisted of } 4 \text { weeks of drug titration and } 2 \text { weeks of } \\
\text { maintenance, followed by } 2 \text { week washout, during which doses } \\
\text { were tapered }\end{array}$ \\
\hline
\end{tabular}

Outcomes (measures) and time points

, Leg pain (0-10 scale), adverse events at 8 weeks

Baron $2010^{23} \quad$ Source: 46 centres in 8 countries; $n=217$; group Group 1: oral pregabalin, 5 weeks at optimal dose established \% of improved patients, adverse $1=110$ (mean (SD) age $53(11)$ ), group 2=107 in single blind phase) $v$ group 2: oral placebo (pregabalin dose events on day $7,14,21,28$, and (53 (13)); duration: chronic (>3 months) tapered off during first 7 days, then placebo administered for 35 4 weeks). Trial started after 1 week single blind run-in phase to identify and exclude placebo responders, followed by 4 week single blind pregabalin treatment phase with flexible dose pregabalin $150-600 \mathrm{mg} /$ day to identify responders. Additional analgesics allowed

Muscle relaxants $v$ placebo

Berry and Source: outpatients from general practices; Group 1: $4 \mathrm{mg}$ oral tizanidine 3 times/day for 7 days $v$ group $\%$ of improved patients on day 3 Hutchinson, $1988^{24} \mathrm{n}=117$; group $1=28$ (mean (SD) age $44(13)$ ), 2: oral placebo ( 3 times/day for 7 days). Additional analgesics and 7 group 2=31(38 (13)); duration: acute (NS) allowed

\section{NSAID $v$ NSAID*}

Borms $1988^{25}$

Source: NS; $n=40$; group 1=20 (mean (SD) age Group 1: twice daily $200 \mathrm{mg}$ IM tiaprofenic twice/day for 4 $37(10))$, group $=20(42(15))$; duration: mixed days $v$ group 2: $100 \mathrm{mg}$ IM ketoprofen twice/day for 4 days (<6 months)

Overall pain (0-100 scale), and 4

Scheurmans Source: NS; $n=26$; group 1=14 (mean (SD) 50 Group 1: $200 \mathrm{mg}$ IM tiaprofenic twice/day for 4 days $v$ group Overall pain (0-100 scale),

$\left.1988^{40}(9)\right)$, group 2=12 (49 (13)); duration: mixed (<6 2: $656 \mathrm{mg} \mathrm{IM}$ alclofenac twice/day for 4 days months) adverse events on days $1,2,3$, and 4

Rachid 1992 $2^{39} \quad$ Source: NS; $n=60 ;$ group 1=30 (mean (range) Group 1: 100 mg/day IM intramuscular injections of ketoprofen Overall pain (0-100 scale), age 51 (29-68)), group 2=30 (53 (26-60)); twice/day for 7 days $v$ group 2: $75 \mathrm{mg} /$ day IM diclofenac adverse events on days 1, 2, 3 , duration: mixed (<12 weeks) twice/day for 7 days $4,5,6$, and 7

Auvinet 1995 22 Source: 22 centres in three countries; $\mathrm{n}=113$; Group 1: IM meloxicam (15 mg in $1.5 \mathrm{ml}$ aqueous solution) Overall pain (0-100 scale), group 1=54 (mean (SD) age $47(10)$ ), group and oral placebo (1 capsule) $v$ group 2: $15 \mathrm{mg}$ oral meloxicam adverse events at 15, 30, 45, 60, 2=59 (42 (11)); duration: acute ( $<35$ days) capsule and one $1.5 \mathrm{ml}$ IM placebo injection. Patients kept on 75 , and $90 \mathrm{~min}$ and 2, 3, 4, 6, 9 strict bed rest during 24 hour study 24 hours

NSAID $v$ corticosteroids combination

Braun $1982^{26} \quad$ Source: NS; $n=37$; group 1=17, group 2=20); age: NS; duration: NS

Group 1: $2 \times 200 \mathrm{mg} /$ day IM ketoprofen on days 1-3, (200 Overall pain (0-100 scale) on day $\mathrm{mg} /$ day), $4 \times 50 \mathrm{mg}$ oral $+1 \times 100 \mathrm{mg}$ suppository ketoprofen on 4 and 9 days 4-8 $v$ group 2: 1 st-3rd day 1 IM combination (phenylbutazone, carbamoyl-phenoxyacetic acid, dexamethasone, lidocaine (lignocaine) hydrochloride, cyanocobalamin) on days $1-3,3$ oral capsules +1 suppository on days 4-8. Additional analgesics allowed

\section{NSAID $v$ caudal epidural injection}

Dincer $2007^{27} \quad$ Source: NS; $n=64$; group $1=30$ (mean (SD)
age $29(6))$, group $2=34(28(6))$; duration: mixed ( $>1$ month to $<12$ months)

Group 1: $75 \mathrm{mg}$ oral diclofenac twice/day for 14 days $v$ group Overall pain ( 0 - 10 scale), 2: single injection (40 mg methylprednisolone acetate, $8 \mathrm{mg}$ disability (ODI) on day 15 and at dexamethasone phosphate, $7 \mathrm{ml} 2 \%$ prolocaine $\mathrm{HCl}, 10 \mathrm{ml} 1$ and 3 months $0.9 \% \mathrm{NaCl}$ ). Both groups instructed to perform lumbopelvic mobilisation and lumbar stabilisation exercise on daily basis. Additional analgesics allowed after day 14

NSAID $v$ acupuncture

Wang 2004 $\quad$ Source: outpatients from acupuncture centre; Group 1: $25 \mathrm{mg}$ oral diclofenac twice/day for 5 days $v$ group Leg pain (0-10 scale) on day 7 $\mathrm{n}=40$; group $1=23$, group $2=17$; age: NS; $\quad 2$ : 25 minute electroacupuncture/day for 7 days duration: chronic $(>2$ years)

NSAID $v$ antidepressant

Kanayama $2005^{36}$ Source: hospital (orthopaedic department); Group 1:75 mg oral diclofenac $v$ group 2: $300 \mathrm{mg}$ oral 5-HT Leg and back pain (0-100 scale) $\mathrm{n}=40$; group $1=20$ (mean (SD) age $34(17)$ ), inhibitor for 2 weeks at 2 weeks group 2=20 $32(9))$; duration: mixed $(<1$ to $>3$ months)

Opioid analgesic $v$ antidepressant $v$ placebo 
Table 2 (continued)

\begin{tabular}{|c|c|c|c|}
\hline Study & Details of participants & Interventions (dose regimens and dosing duration) & $\begin{array}{c}\text { Outcomes (measures) and time } \\
\text { points }\end{array}$ \\
\hline $\begin{array}{l}\text { Khoromi } 2007^{37} \\
\text { (crossover study) }\end{array}$ & $\begin{array}{l}\text { Source: recruited through local newspaper } \\
\text { advertisements; } n=28 \text {; age: } 53 \text { (range 19-65); } \\
\text { duration: chronic ( } \geq 3 \text { months) }\end{array}$ & $\begin{array}{l}\text { Group } 1: 15 \mathrm{mg} \text { oral sustained release morphine } v \text { group } 2 \text { : } \\
25 \mathrm{mg} \text { oral nortriptyline } v \text { group } 3: 15 \mathrm{mg} \text { oral morphine }+25 \\
\text { mg nortriptyline } v \text { group } 4 \text { : oral inert placebo }(0.25 \mathrm{mg} \\
\text { benztropine, mimics side effects of other). All drugs tapered } \\
\text { over } 10 \text { day period and patients drug-free for another } 4 \text { days } \\
\text { before starting next period. Doses above are starting doses, } \\
\text { subsequent doses depended on tolerability }\end{array}$ & $\begin{array}{l}\text { Leg and back pain }(0-10) \text {, } \\
\text { disability (ODI), adverse events, } \\
\text { day } 10\end{array}$ \\
\hline
\end{tabular}

$\mathrm{IM}=$ intramuscular; $\mathrm{NS}=$ not specified; IV=intravenous. ODI=Oswestry disability index. NSAID=non-steroidal anti-inflammatory drug. RM=Roland Morris disability questionnaire.

${ }^{*}$ Dreiser $^{28}$ and Herman ${ }^{33}$ could be included in this comparison as both studies included comparisons of NSAID $v$ NSAID. 


\begin{tabular}{|c|c|c|c|c|c|c|c|c|c|c|c|}
\hline Study & $\begin{array}{l}\text { Random } \\
\text { allocation }\end{array}$ & $\begin{array}{l}\text { Concealed } \\
\text { allocation }\end{array}$ & $\begin{array}{l}\text { Groups } \\
\text { similar at } \\
\text { baseline }\end{array}$ & $\begin{array}{l}\text { Participant } \\
\text { blinding }\end{array}$ & $\begin{array}{l}\text { Therapist } \\
\text { blinding }\end{array}$ & $\begin{array}{l}\text { Assessor } \\
\text { blinding }\end{array}$ & $\begin{array}{c}<15 \% \\
\text { dropouts }\end{array}$ & $\begin{array}{l}\text { Intention } \\
\text { to treat } \\
\text { analysis }\end{array}$ & $\begin{array}{l}\text { Between } \\
\text { group } \\
\text { difference } \\
\text { reported }\end{array}$ & $\begin{array}{c}\text { Point } \\
\text { estimate and } \\
\text { variability } \\
\text { reported }\end{array}$ & $\begin{array}{l}\text { Total } \\
(0-10)\end{array}$ \\
\hline Grevsten $1975^{31}$ & Yes & No & No & Yes & No & Yes & Yes & No & Yes & Yes & 6 \\
\hline Weber $1993^{42}$ & Yes & No & Yes & Yes & No & Yes & Yes & No & No & No & 5 \\
\hline Dreisser $2001^{28 *}$ & Yes & No & Yes & Yes & No & Yes & Yes & Yes & Yes & Yes & 8 \\
\hline Herrmann $2009^{33}$ & Yes & Yes & Yes & Yes & Yes & Yes & Yes & Yes & Yes & No & 9 \\
\hline Hofferberth $1982^{34}$ & Yes & Yes & No & Yes & Yes & Yes & Yes & Yes & Yes & No & 8 \\
\hline Haimovic $1986^{32}$ & Yes & No & No & Yes & No & Yes & Yes & No & No & Yes & 5 \\
\hline Finckh $2006^{29}$ & Yes & Yes & Yes & Yes & Yes & Yes & Yes & No & Yes & No & 8 \\
\hline Holve $2008^{35}$ & Yes & No & Yes & Yes & Yes & Yes & No & No & Yes & Yes & 7 \\
\hline Friedman $2008^{30}$ & Yes & Yes & Yes & Yes & Yes & Yes & Yes & No & Yes & Yes & 9 \\
\hline Atkinson $1998^{21}$ & Yes & Yes & Yes & Yes & Yes & Yes & No & Yes & Yes & Yes & 9 \\
\hline Yildirim $2003^{43}$ & Yes & No & Yes & Yes & No & Yes & Yes & No & Yes & Yes & 7 \\
\hline Khoromi $2005^{38}$ & Yes & No & No & Yes & Yes & Yes & No & No & Yes & Yes & 6 \\
\hline Baron $2010^{23}$ & Yes & Yes & No & Yes & Yes & Yes & No & Yes & Yes & Yes & 8 \\
\hline Berry $1988^{24}$ & Yes & No & Yes & Yes & No & Yes & Yes & No & Yes & Yes & 7 \\
\hline Borms $1988^{25}$ & Yes & No & No & No & No & No & Yes & No & Yes & Yes & 4 \\
\hline Scheurmans $1988^{40}$ & Yes & No & Yes & No & No & No & Yes & No & Yes & Yes & 5 \\
\hline Rachid $1992^{39}$ & Yes & No & Yes & No & No & No & No & No & Yes & No & 3 \\
\hline Auvinet $1995^{22}$ & Yes & No & Yes & Yes & No & Yes & Yes & Yes & Yes & Yes & 8 \\
\hline Braun $1982^{26}$ & Yes & No & No & Yes & No & Yes & Yes & Yes & Yes & No & 6 \\
\hline Dincer $2007^{27}$ & Yes & No & Yes & No & No & No & Yes & No & Yes & Yes & 5 \\
\hline Wang $2004^{41}$ & Yes & No & Yes & No & No & No & Yes & No & Yes & Yes & 5 \\
\hline Kanayama $2005^{36}$ & Yes & Yes & No & No & No & No & Yes & No & Yes & Yes & 5 \\
\hline Khoromi $2007^{37}$ & Yes & No & No & Yes & Yes & Yes & No & Yes & Yes & Yes & 7 \\
\hline
\end{tabular}

${ }^{*}$ Dreisser et $\mathrm{al}^{28}$ reported on two clinical trials. 


\begin{tabular}{|c|c|c|c|c|c|}
\hline Study & Group 1 & Group 2 & Group 3 & Group 4 & Description of adverse events \\
\hline Grevsten $1975^{31}$ & $\begin{array}{l}\text { Phenylbutazone 0.1-0.6 (3/18; } \\
16 \%)\end{array}$ & Placebo (4/18; 22\%) & NS & NS & Mild transient nausea (6); gastritis (1) \\
\hline Weber $1993^{42}$ & $\begin{array}{l}\text { Piroxicam } 20 \text { mg (22/120; } \\
18 \%)\end{array}$ & Placebo $(13 / 94 ; 14 \%)$ & NS & NS & Not explicitly stated \\
\hline $\begin{array}{l}\text { Dreisser } 2001^{28} \text { (trial } \\
\text { 1) }\end{array}$ & $\begin{array}{l}\text { Meloxicam } 7.5 \text { mg }(9 / 117 \\
8 \%)\end{array}$ & $\begin{array}{l}\text { Meloxicam } 15 \mathrm{mg} \\
(13 / 181 ; 7 \%)\end{array}$ & $\begin{array}{l}\text { Placebo }(8 / 180 \\
4 \%)\end{array}$ & NS & $\begin{array}{l}\text { Abdominal pain (7); diarrhoea (3); dizziness ( } 3 \text {; } \\
\text { dyspepsia ( } 7) \text {; hepatic enzymes increased (2); } \\
\text { nausea (8) }\end{array}$ \\
\hline $\begin{array}{l}\text { Dreisser } 2001^{28} \text { (trial } \\
\text { 2) }\end{array}$ & $\begin{array}{l}\text { Meloxicam } 7.5 \mathrm{mg}(21 / 164 \text {; } \\
13 \%)\end{array}$ & $\begin{array}{l}\text { Meloxicam } 15 \mathrm{mg} \\
(27 / 163 ; 17 \%)\end{array}$ & $\begin{array}{l}\text { Diclofenac } \\
(24 / 162 ; 15 \%)\end{array}$ & NS & $\begin{array}{l}\text { Abdominal pain (10); diarrhoea (10); dizziness (5); } \\
\text { dyspepsia (21); flatulence (6); headache (9); nausea } \\
\text { (11) }\end{array}$ \\
\hline Herrmann $2009^{33}$ & Lornoxicam 8 mg (6/57; 11\%) & $\begin{array}{l}\text { Diclofenac } 50 \text { mg }(7 / 57 ; \\
12 \%)\end{array}$ & $\begin{array}{l}\text { Placebo }(4 / 57 \\
7 \%)\end{array}$ & NS & $\begin{array}{l}\text { Dyspepsia (5); diarrhoea (5); nausea (4); abdominal } \\
\text { pain (3); flatulence (1); bronchitis (1), coughing (1), } \\
\text { sputum (w2), hyperuricaemia (2), bilirubinaemia } \\
\text { (1), myalgia (1), leg cramps (1) }\end{array}$ \\
\hline Hofferberth $1982^{34}$ & $\begin{array}{l}\text { Dexamethasone } 168 \mathrm{mg} \\
(13 / 38 ; 34 \%)\end{array}$ & Placebo $(4 / 53 ; 8 \%)$ & NS & NS & Epigastric complaints \\
\hline Finckh $2006^{29}$ & $\begin{array}{l}\text { Methylprednisolone } 500 \mathrm{mg} \\
(3 / 31 ; 10 \%)\end{array}$ & Placebo (0) & NS & NS & Transient hyperglycaemia (2); facial flush (1) \\
\hline Holve $2008^{35}$ & Prednisolone $20-60$ mg (0) & Placebo (0) & NS & NS & - \\
\hline Friedman $2008^{30}$ & $\begin{array}{l}\text { Methylprednisolone } 160 \mathrm{mg} \\
(11 / 39 ; 28 \%)\end{array}$ & Placebo $(8 / 43 ; 19 \%)$ & NS & NS & $\begin{array}{l}\text { Drowsiness (11); stomach pain (6); mood changes } \\
\text { (1); bloating (1) }\end{array}$ \\
\hline Yildirim $2003^{43}$ & $\begin{array}{l}\text { Gabapentin } 900-3600 \mathrm{mg} \\
(2 / 25 ; 8 \%)\end{array}$ & Placebo (0) & NS & NS & $\begin{array}{l}\text { Dizziness (1); somnolence (1); chest pain (1); } \\
\text { fainting (1) }\end{array}$ \\
\hline Khoromi $2005^{38 *} \dagger$ & $\begin{array}{l}\text { Topiramate } 50-400 \mathrm{mg} \\
(24 / 28 ; 86 \%)\end{array}$ & Placebo (20/28; 72\%) & NS & NS & $\begin{array}{l}\text { Paraesthesia (17); fatigue/weakness (19); sedation } \\
\text { (11); diarrhoea (11); headache (6); constipation (2); } \\
\text { depression (2); joint pain (3); leg cramps (7); } \\
\text { amnesia (1); anorexia (1); frequent urination (1); } \\
\text { thirst (1); eyes twitching (1); oedema (1); speech } \\
\text { difficulty (1); blurred vision (1); photophobia (1); } \\
\text { bleedings gums (1); tremor (1); somnolence (1); } \\
\text { extremely yellow urine (1); decreased libido (1) }\end{array}$ \\
\hline Baron $2010^{23} \ddagger$ & $\begin{array}{l}\text { Pregabalin } 150-600 \mathrm{mg} \\
(31 / 110 ; 28 \%)\end{array}$ & Placebo $(26 / 107 ; 24 \%)$ & NS & NS & $\begin{array}{l}\text { Dizziness (6); somnolence (2); fatigue (2); dry } \\
\text { mouth (2); constipation (1); headache (5); weight } \\
\text { increase (5); peripheral oedema (7). }\end{array}$ \\
\hline Borms $1988^{25}$ & $\begin{array}{l}\text { Tiaprofenic } 400 \text { mg }(6 / 20 \\
30 \%)\end{array}$ & $\begin{array}{l}\text { Ketoprofen } 200 \text { mg (9/20; } \\
45 \%)\end{array}$ & NS & NS & $\begin{array}{l}\text { Stomach pain (7); allergic skin reaction (3); pain on } \\
\text { injection (3); dizziness (1); headache (1) }\end{array}$ \\
\hline Scheurmans $1988^{40}$ & $\begin{array}{l}\text { Tiaprofenic } 400 \text { mg (2/14; } \\
\text { 14\%) }\end{array}$ & 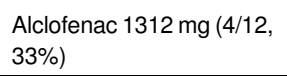 & NS & NS & $\begin{array}{l}\text { Pruritus (1); pain on injection (1); allergic skin } \\
\text { reaction (2); gastralgia (2); vertigo (1) }\end{array}$ \\
\hline Rachid $1992^{39}$ & $\begin{array}{l}\text { Ketoprofen } 200 \text { mg (11/30; } \\
37 \%)\end{array}$ & $\begin{array}{l}\text { Diclofenac } 150 \text { mg (10/30; } \\
33 \%)\end{array}$ & NS & NS & Epigastric pain (9); nausea (11), pyrosis (6). \\
\hline Auvinet $1995^{22}$ & $\begin{array}{l}\text { IM meloxicam } 15 \text { mg }(5 / 52 \text {; } \\
9 \%)\end{array}$ & $\begin{array}{l}\text { Oral meloxicam } 15 \mathrm{mg} \\
(6 / 59 ; 10 \%)\end{array}$ & NS & NS & $\begin{array}{l}\text { Erythematous rash (1); dizziness (1); headache (3); } \\
\text { dry mouth (2); palpitations (1); neutropenia (1); } \\
\text { leucopenia (1); nocturia (1) }\end{array}$ \\
\hline Braun $1982^{26}$ & Ketoprofen 200 mg (0) & $\begin{array}{l}\text { Combination preparation } \\
(0)\end{array}$ & NS & NS & - \\
\hline Khoromi $2007^{37 \star}$ & $\begin{array}{l}\text { Nortriptyline } 25 \text { mg (19/28; } \\
68 \%)\end{array}$ & $\begin{array}{l}\text { Morphine } 15 \mathrm{mg}(26 / 28 \\
93 \%)\end{array}$ & $\begin{array}{l}\text { Combination } \\
(25 / 28 ; 89 \%)\end{array}$ & $\begin{array}{l}\text { Placebo } \\
(14 / 28 ; 50 \%)\end{array}$ & $\begin{array}{l}\text { Constipation (47); dry mouth (30); headache (14); } \\
\text { drowsiness (13); tired/fatigue (19); dizziness (8); } \\
\text { insomnia (8); nausea (3); difficulty urinating (4); } \\
\text { sexual dysfunction (4); abdominal pain (4); } \\
\text { weakness (2); decreased appetite (3); heartburn } \\
\text { (4); blurred vision (6); thirsty/dehydrated (2); weight } \\
\text { gain (2) }\end{array}$ \\
\hline
\end{tabular}

$\mathrm{NA}=$ not stated; IM=intramuscular.

${ }^{*}$ Crossover study and adverse effects only for completers.

†Nine patients dropped out from study because of adverse effects of topiramate: acral paraesthesia (2); nausea and anorexia (2); sedation and amnesia (3); depression and anxiety (1); rash (1).

‡Only most common adverse events listed. 


\section{Figures}

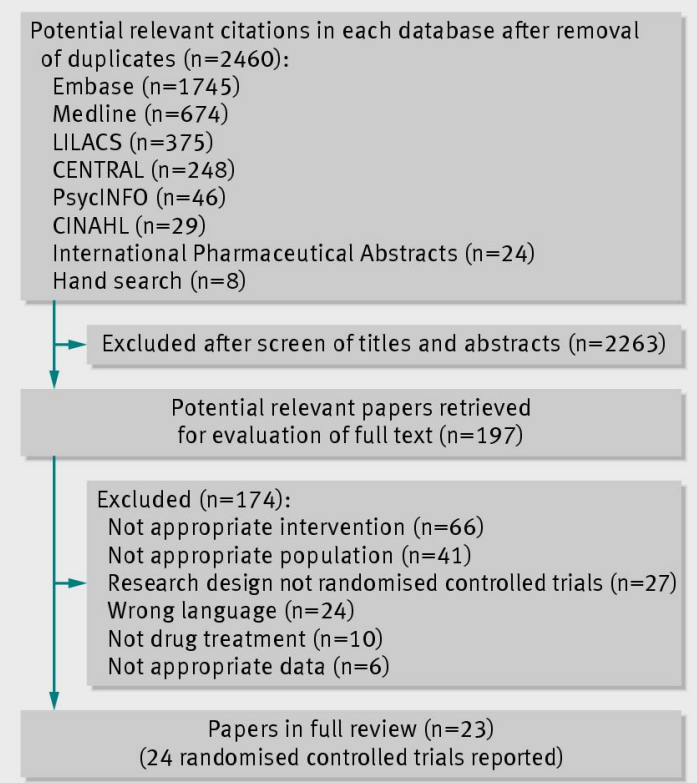

Fig 1 Selection process of trials examining pain relief in patients with sciatica 


\section{Study}

NSAIDs $v$ placebo

Dreiser $2001^{28}$

Meloxicam $7.5 \mathrm{mg}$

Meloxicam $15 \mathrm{mg}$

Herrmann $2009^{33}$

Lornoxicam $8 \mathrm{mg}$

Diclofenac 50-150 mg

Weber $1993^{42}$

Piroxicam $20 \mathrm{mg}$

\section{Corticosteroids $\boldsymbol{v}$ placebo}

Holve $2008^{35}$

Prednisone $20-60 \mathrm{mg}$

Friedman $2008^{30}$

Methylprednisolone $160 \mathrm{mg}$ Overall pain/short term $\quad-71.0(30.0) \quad 37 \quad-58.0(35.0) \quad 41$ Finckh $2006^{29}$

Methylprednisolone $500 \mathrm{mg}$ Leg pain/immediate Leg pain/short term

$-27.7(22.1) \quad 31 \quad-26.6(20.7) \quad 29$ $-31.0(22.1) \quad 31 \quad-20.0(20.7) \quad 29$

\section{Anticonvulsant $v$ placebo}

Yildirim $2003^{43}$

Gabapentin 900-3600 mg Overall pain/short term $18.7(19.3) \quad 23 \quad 45.3(19.7) \quad 20$ Khoromi $2005^{38}$

Topiramate $50-400 \mathrm{mg}$

Antidepressant $\boldsymbol{v}$ placebo

Khoromi $2007^{37}$

Nortriptyline $25 \mathrm{mg}$

Opioid analgesics $v$ placebo

Khoromi $2007^{37}$

Morphine $15 \mathrm{mg}$

\section{Antidepressant + opioid analgesics $\boldsymbol{v}$ placebo \\ Khoromi $2007^{37}$}

Nortriptyline $25 \mathrm{mg}$

+ morphine $15 \mathrm{mg}$

\section{Drug treatment Placebo}

$\overline{\text { Mean (SD) Total Mean (SD) Total }}$

Overall pain/immediate $-46.0(25.7) \quad 165-40.0(25.9) \quad 168$ Overall pain/immediate $-45.0(25.9) \quad 167 \quad-40.0(25.9) \quad 168$

Overall pain/immediate $-22.0(25.8) \quad 53 \quad-13.7(25.8) \quad 56$ Overall pain/immediate -24.0 (25.8) $55 \quad-13.7$ (25.8) 56 gain/short term pain/immediate Disability/immediate $40.0(25.6) \quad 120 \quad 40.0(25.6) \quad 94$ $21.0(25.6) \quad 120 \quad 18.0(25.6) \quad 94$ $43.0(25.6) \quad 120 \quad 40.0(25.6) \quad 94$ $22.0(25.6) \quad 120 \quad 17.0(25.6) \quad 94$ $40.6(25.6) \quad 120 \quad 25.9(25.6) \quad 94$ $28.8(25.6) \quad 120 \quad 25.9(25.6) \quad 94$ $\begin{array}{lllll}\text { Back pain/immediate } & 33.3(24.7) & 29 & 42.0(24.7) & 29\end{array}$ Disability/immediate $\quad 25.0(16.0) \quad 29 \quad 27.0(15.0) \quad 29$

Leg pain/immediate $\quad 30.0(27.0) \quad 28 \quad 37.0(27.0) \quad 28$ Back pain/immediate $29.0(24.0) \quad 28 \quad 38.0(25.0) \quad 28$ Disability/immediate $\quad 27.5(16.7) \quad 28 \quad 30.5(15.9) \quad 28$

Leg pain/immediate $\quad 34.0(28.0) \quad 28 \quad 37.0(27.0) \quad 28$ $\begin{array}{lllll}\text { Back pain/immediate } \quad 34.0(25.0) & 28 & 38.0(25.0) & 28\end{array}$ Disability/immediate $25.7(16.5) \quad 28 \quad 30.5(15.9) \quad 28$

Leg pain/immediate $\quad 34.0(25.0) \quad 28 \quad 37.0(27.0) \quad 28$ $\begin{array}{lllll}\text { Back pain/immediate } \quad 32.0(24.0) & 28 & 38.0(25.0) & 28\end{array}$ Disability/immediate $27.4(15.4) \quad 28 \quad 30.5(15.9) \quad 28$

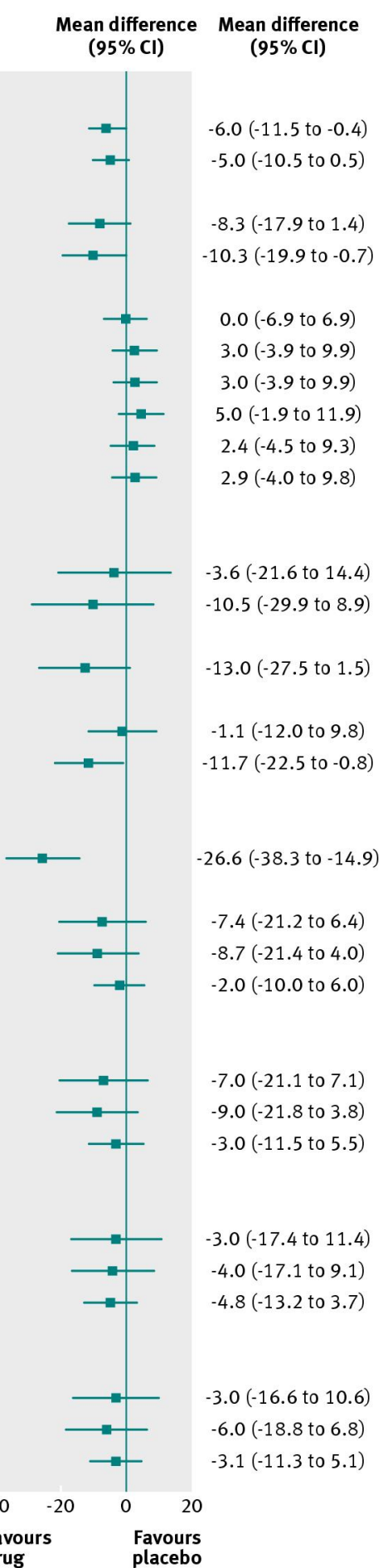

$\begin{array}{ll}\text { Favours } & \text { Favours } \\ \text { drug } & \text { placebo }\end{array}$

Fig 2 Mean difference for pain and disability in placebo controlled trials on pain relief in patients with sciatica. Overall pain, leg pain, back pain, and disability expressed on common 0-100 scale. Immediate=follow-up evaluations $\leq 2$ weeks after randomisation; short term=follow-up evaluations $>2$ weeks but $\leq 3$ months; intermediate=follow-up evaluations $>3$ months but $<12$ months; long term= $\geq 12$ months. NSAID=non-steroidal anti-inflammatory drug 


\section{Study}

NSAIDs $v$ placebo (outcome: pain/immediate)

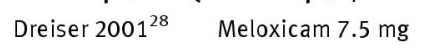

\section{Drug treatment Placebo}

$-46.0(25.7) 165-40.0(25.9) 168$

$-24.0(25.8) \quad 55 \quad-13.7(25.8) \quad 56$

$40.0(25.6) \quad 120 \quad 40.0(25.6) \quad 94$

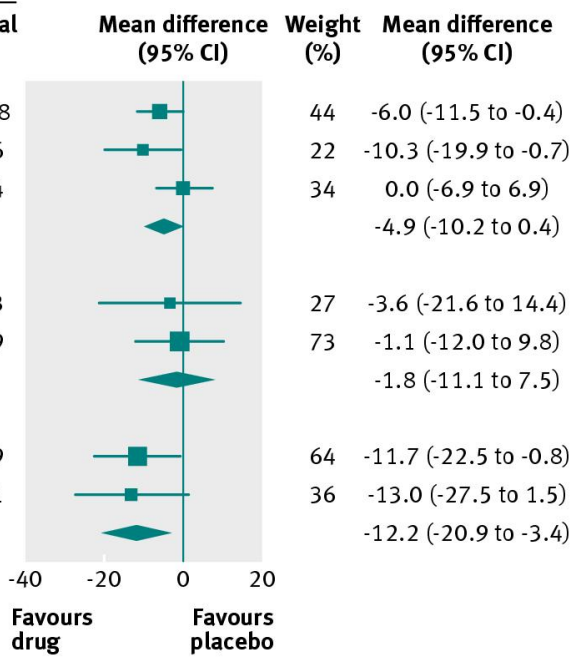

Fig 3 Pooled mean difference for immediate pain in trials comparing NSAID $v$ placebo. Pain expressed on common 0-100 scale. Immediate=follow-up evaluations $\leq 2$ weeks after randomisation; short term=follow-up evaluations $>2$ weeks but $\leq 3$ months; intermediate=follow-up evaluations $>3$ months but $<12$ months; long term= $\geq 12$ months. NSAID=non-steroidal anti-inflammatory drug

\section{Study}

\section{NSAIDs $v$ NSAIDs}

Rachid $1992^{39}$

Diclofenac $150 \mathrm{mg} v$ ketoprofen $200 \mathrm{mg}$ Dreiser $2001^{28}$

Diclofenac $150 \mathrm{mg} v$ meloxicam $7.5 \mathrm{mg}$

Diclofenac $150 \mathrm{mg} v$ meloxicam $15 \mathrm{mg}$

Hermann $2009^{32}$

Diclofenac 50-150 mg $v$ lornoxicam $8 \mathrm{mg}$ Schuermans $1988^{40}$

Tiaprofenac $400 \mathrm{mg} v$ alclofenac $1312 \mathrm{mg}$ Borms $1988^{25}$

Tiaprofenac $400 \mathrm{mg} v$ ketoprofen $200 \mathrm{mg}$ Auvinet $1995^{22}$

Meloxicam $15 \mathrm{mg}$ (oral $v$ intramuscular)

NSAIDs $\boldsymbol{v}$ antidepressants

Kanayama $2005^{36}$

Diclofenac $75 \mathrm{mg} v 5$-HT inhibitor

NSAIDs $v$ conservative treatment

Wang $2004^{41}$

Diclofenac $50 \mathrm{mg} v$ electroacupuncture NSAIDs $v$ corticosteroids

Dincer $2007^{27}$

Diclofenac $75 \mathrm{mg} v$ caudal epidural injection*

Braun $1982^{26}$

Ketoprofen $200 \mathrm{mg} v$ corticosteroids combination

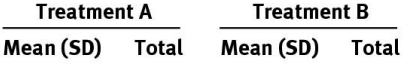

Overall pain/immediate

$27.2(25.6)$

Overall pain/immediate

Overall pain/immediate

$-40.0(24.0) \quad 144$

$-40.0(24.0) \quad 144$

Overall pain/immediate

$-24.0(25.8) \quad 55 \quad-22.0(25.8) \quad 53$

Overall pain/immediate

$20.2(29.7) \quad 13 \quad 23.5(22.8) \quad 10$

Overall pain/immediate

$19.7(22.9) \quad 17 \quad 36.0(28.2) \quad 16$

Overall pain/immediate

$32.6(18.2) \quad 46 \quad 27.2(20.2) \quad 52$

Leg pain/immediate

Back pain/immediate

$39.0(34.0)$

36.0

Leg pain/immediate

(15)

$21.0(25.6) \quad 21$

Overall pain/immediate Overall pain/short term Disability/immediate Disability/short term

$\begin{array}{cccc}53.0(9.0) & 30 & 33.0(9.0) & 34 \\ 41.0(15.0) & 30 & 33.0(13.0) & 34 \\ 28.4(5.4) & 30 & 19.5(6.4) & 34 \\ 20.3(10.1) & 30 & 16.2(9.4) & 34 \\ & & & \\ 42.5(25.6) & 17 & 39.2(25.6) & 20\end{array}$

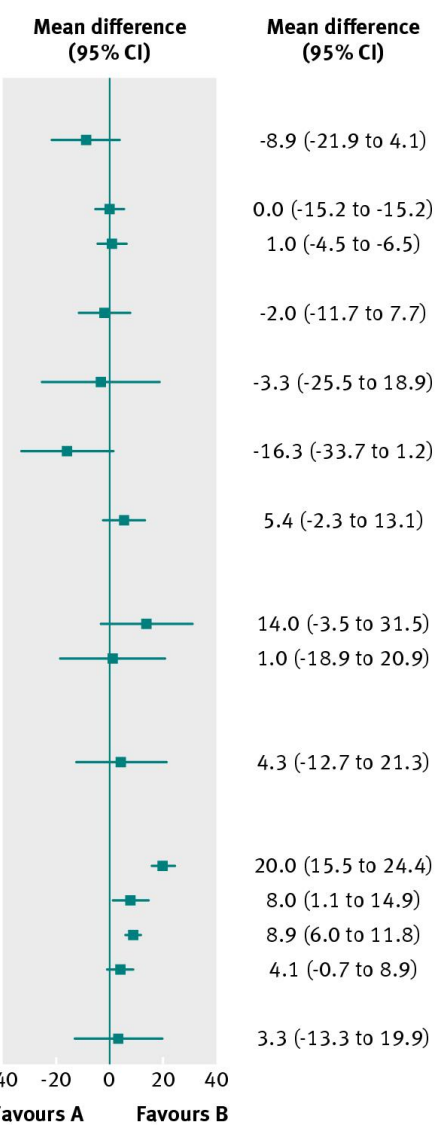

Favours A Favours B

Fig 4 Mean difference for pain and disability in trials comparing NSAID versus NSAID or other treatments. Overall pain, leg pain, back pain and disability expressed on common 0-100 scale. Immediate=follow-up evaluations $\leq 2$ weeks after randomisation; short term=follow-up evaluations $>2$ weeks but $\leq 3$ months; intermediate=follow-up evaluations $>3$ months but $<12$ months; long term $=\geq 12$ months. NSAID=non-steroidal anti-inflammatory drug. *Injection contains methylprednisolone $40 \mathrm{mg}$, dexamethasone $8 \mathrm{mg}, 2 \%$ prolocaine $7 \mathrm{ml}, 0.9 \% \mathrm{NaCL} 10 \mathrm{ml}$ ) 